\section{Fasella offers to take advice}

London

THE key words to describe the pattern of support for collaborative research in Europe after 1992 are "decentralized" and "flexible", according to Paolo Fasella, director-general of DG XII, the European Commission's directorate-general responsible for science policy. There will be no more "white elephants" in the form of new supranational European research centres; instead existing national laboratories will take on a "European function", perhaps for a limited period of time.

In a discussion meeting last week on the future of biological research attended by a select group of Britain's biologists and science policy-makers, Fasella rejected the idea of laboratories with a permanent "EC label". Research would be more efficient and effective if research institutes currently recognized as national centres of excellence were awarded grants for three to five years, he said, during which time they would be expected to recruit the best of Europe's researchers in that field and cooperate with a network of "satellite" laboratories carrying out relevant research.

Fasella also outlined the Commission's ideas on an "Assembly of Scientists and Technologists" to act as an independent advisory body to the Commission (see Nature 338, 734; 27 April 1989). Fasella said the Assembly would consist of 100 200 advisors loosely grouped together to form a self-governing group.

Although members would receive no salary, just "tourist fare travel expenses and sandwiches", says Fasella, they would be expected to initiate enquiries as well as to respond to requests for advice, and the Assembly would be funded by DG XII's current budget for paying consultants. This parsimony was strongly criticized by many at the discussion meeting. Expressing a common view, Professor John Ziman of the Science Policy Support Group said that the Assembly could not be successful without adequate finance and administrative support. But Fasella's broad plan to improve the "haphazard" manner in which advice on scientific and technological matters is provided at present was warmly welcomed.

The trade war with the United States after a European ban on steroid hormones in meat was cited as an example of the problems that can result from inadequate advice to European policy-makers. And unnecessarily tight regulations on the levels of nitrates in water "had a good chance of wiping out Europe's horticultural industry" because of high costs, complained Professor Bill Stewart, head of Britain's Agricultural and Food Research Council.

Fears about manpower haunt many discussions among British researchers about the future of the biological sciences in Britain, and last week's discussion was no different. Departmental heads say that for the first time it is difficult to fill research studentships.

In an attempt to draw attention to this problem, a group of biologists led by Professor C.F. Higgins of the University of Dundee, sought endorsement from academics and industrialists for a letter to the Secretary of State for Education and Science, Kenneth Baker, and the heads of the research councils, in which they urge for action to be taken to improve the salary and career structure for young researchers. The poor prospects for researchers is causing graduates to choose other professions and creating an "internal brain-drain", the letter says. Signed by more than 100 heads of biological sciences departments, almost 700 tenured academics and 21 industralists, it calls for "immediate action at the highest level" to find a "radical solution" to the problem.

Christine McGourty

\section{Staab floats three ideas}

\section{Wesbaden}

MAx Planck Society President Heinz Staab put forward three proposals to strengthen scientific cooperation in the European Community (EEC) at the society's annual meeting here last week.

First, Staab proposed the institution of European research conferences modelled on the Gordon Conferences in the United States. Second, he recommended a European exchange programme for postdoctoral candidates to allow qualified people from one member country to carry out research at institutes elsewhere in the community. And third, on behalf of the German Research Ministry (BMFT), he announced a readiness to support collaborations between individual West German researchers and individual researchers in other countries.

The first two programmes would be supported by the European Community, if funds are available, but administrated by the European Science Foundation. The conferences would be held "away from the city", he said, just like the Gordon Conferences in New Hampshire. Each conference would bring together about 100 persons in a narrow subject area for lectures and discussions.

Staab reported that both DG XII's Paolo Fasella and Maria Filippo Pandolfi, Vice-President of the Commission for Science, Research and Development, were receptive to the idea.

Steven Dickman

\section{Ariane gets heavy}

AFTER a 10-day delay, the European commercial satellite consortium, Arianespace, launched its largest Ariane-4 rocket so far on 5 June. On board were two telecommunications satellites, the US-built SuperbirdA for the Japanese Space Communications Corporation and DFS Kopernikus-1, belonging to the West German Deutsche Bundespost. The Ariane-44L needed a total lift performance of $4,418 \mathrm{~kg}$, putting it in the 'heavyweight' class that Arianespace needs to keep its commercial edge in the 1990 s, in the face of a return of US launchers in the private sector. Chinese and Japanese launchers will also be seeking a slice of the $\$ 1,000$ million-a-year commercial launch market.

This year, the Ariane series celebrates its tenth anniversary. With 13 successful launches in the past $\mathbf{2 1}$ months, Arianespace has shown that it has recovered from the technical difficulties of 1986 which held up launches for over a year.

P.C.

\section{AIDS white paper}

ThE Australian Government released its first white paper on AIDS last week, recommending that all foreigners wishing to settle in Australia be tested for AIDS and that the possession of small quantities of illegal drugs for personal use be decriminalized. The policy document will be presented to the Cabinet after a period of public consultation lasting a year. Other recommendations include establishing needleexchange and disposal centres in all states, testing all prisoners for the AIDS virus, making condoms available in prisons and banning home AIDS-test kits.

Its most controversial recommendation is for a review of Commonwealth censorship and broadcasting laws. The review is designed to prevent a repeat of an incident earlier this year when announcements giving information about AIDS had to be altered substantially because television stations deemed them offensive.

T.E.

\section{Taking the biscuit}

KOALA bears may be popular at zoos throughout the world but they are not easy to keep, given that all they will eat are the leaves of a tiny number of eucalyptus species. But air delivery of fresh Australian eucalyptus leaves to the world's zoos may soon be at an end, thanks to the development of the koala biscuit by Professor Ian Hume of the University of New South Wales and Dr Lester Pahl of the University of New England.

The biscuit is similar in physical and chemical characteristics to the fresh leaves of the three most preferred eucalyptus species. The only problem is the koalas, which Hume accuses of being "fixated with their gum leaves". "Educating the koalas to eat the biscuits is a very long and painful process", he says.

T.E. 